\title{
Pengaruh Penerapan Model Scaffolding terhadap Kemampuan Pemahaman Konsep Matematis Berdasarkan Self Efficacy Siswa SMP
}

\author{
Fakhriatul Masnia ${ }^{1}$, Zubaidah Amir, $\mathbf{M Z}^{2}$ \\ ${ }^{1,2}$ Program studi pendidikan matematika, Universitas Islam Negeri Sultan Syarif Kasim Riau, Indonesia \\ e-mail: zubaidah.amir@uin-suska.ac.id
}

\begin{abstract}
ABSTRAK. Penelitian ini dilatarbelakangi oleh fakta empiris yang menyatakan bahwa rendahnya kemampuan pemahaman konsep matematis siswa di Sekolah Menengah Pertama. Penelitian ini bertujuan untuk mengetahui ada tidaknya perbedaan kemampuan pemahaman konsep matematis antara siswa yang mengikuti model pembelajaran Scaffolding dengan siswa yang belajar mengikuti pembelajaran langsung, jika ditinjau berdasarkan Self Efficacy siswa, dan ada tidaknya pengaruh interaksi penerapan model pembelajaran dengan Self Efficacy siswa terhadap kemampuan pemahaman konsep matematis. Populasi dalam penelitian ini adalah siswa kelas VIII SMP Negeri 40 Pekanbaru. Pengambilan sampel menggunakan Purposive Sampling berdasarkan pertimbangan guru bahwa kemampuan pemahaman konsep dan Self Efficacy siswa tidak berbeda pada kedua kelas. Pengumpulan data dilakukan menggunakan tes dan angket. Instumen tes yang digunakan yaitu tes kemampuan pemahaman konsep matematis berbentuk uraian, sedangkan instrument angket yaitu angket Self Efficacy. Teknik analisis data yaitu uji $\mathrm{t}$ dan uji anova dua arah. Hasil penelitian menunjukkan bahwa: 1) Terdapat perbedaan kemampuan pemahaman konsep matematis siswa yang belajar dengan model pembelajaran Scaffolding dengan siswa yang belajar menggunakan pembelajaran langsung, 2) Jika ditinjau dari Self Efficacy siswa, tidak terdapat perbedaan kemampuan pemahaman konsep matematis siswa yang belajar dengan model pembelajaran Scaffolding dengan siswa yang belajar menggunakan pembelajaran langsung. 3) Tidak terdapat interaksi antara penerapan model pembelajaran dengan Self Efficacy terhadap kemampuan konsep matematis.
\end{abstract}

Kata kunci: Kemampuan Pemahaman Konsep Matematis, Self Efficacy, Scaffolding, Sekolah Menengah Pertama.

\section{PENDAHULUAN}

Matematika merupakan salah satu ilmu bantu yang sangat penting dan berguna dalam kehidupan sehari-hari. Matematika dapat digunakan untuk menemukan jawaban dari permasalahan yang dihadapi oleh manusia.

Pemahaman merupakan suatu dasar yang harus dikuasai oleh siswa, karena tanpa pemahaman siswa akan sulit dalam mengikuti pembelajaran matematika, dan juga dalam menyelesaikan persoalan matematika.Tujuan pembelajaran matematika untuk pendidikan dasar dan menengah yaitu salah satunya agar siswa memahami konsep matematika, menjelaskan keterkaitan antarkonsep dan mengaplikasikan konsep atau algoritma, secara luwes, akurat, efisien, dan tepat, dalam pemecahan masalah (Depdiknas, 2006). Kemampuan pemahaman konsep ini perlu dikembangkan agar siswa dapat dengan mudah memahami konsep, siswa akan terlatih untuk memahami suatu masalah dengan baik, bernalar dengan baik, menganalisis suatu permasalahan sehingga dapat menyelesaikan soal berdasarkan konsep-konsep yang sudah dipelajari.

Namun pada saat ini, pada proses pembelajaran matematika kurang melibatkan aktivitas siswa secara optimal. Ketika pembelajaran berlangsung guru sering mendominasi, sehingga siswa kurang aktif membangun pengetahuannya sendiri (Nicke dkk., 2014). Kurangnya keterlibatan 
siswa di dalam proses pembelajaran membuat siswa kurang dalam memahami konsep-konsep dari matematika tersebut. Siswa tidak terbiasa atau kurang aktif dalam membangun pengetahuan sendiri terhadap pembelajaran matematika.Data empiris mengenai rendahnya kemampuan pemahaman konsep matematis terdapat di SMP Negeri 40 Pekanbaru. Berdasarkan hasil observasi yang dilakukan peneliti melalui wawancara dengan guru Matematika disekolah tersebut rata-rata hasil belajar matematika siswa di sekolah tersebut masih tergolong rendah. Rendahnya nilai rata-rata pada pelajaran matematika ini disebabkan beberapa faktor, yaitu: 1) Sistem pembelajaran berpusat pada guru. 2) Pemahaman konsep matematika siswa masih rendah dikarenakan kurangnya pemahaman siswa terhadap rumus-rumus, sifat-sifat, maupun permasalahan dalam menyelesaikan soal-soal matematika. Hal ini terlihat pada saat siswa diberikan soal matematika dan siswa tidak memahami konsep apa yang bisa dipakai untuk menyelesaikan soal tersebut. 3) Siswa tidak dapat menyelesaikan soal yang berbeda dari contoh soal yang diberikan oleh guru. Hal ini terjadi karena siswa terbiasa menerima pembelajaran dari guru dan hanya mengerti terhadap bentuk-bentuk contoh soal yang diberikan guru dipapan tulis.

Hal ini didukung juga oleh hasil tes kemampuan pemahaman konsep matematis sebagai penelitian awal di sekolah tersebut. Dari hasil tes tersebut, ditemukan, banyak siswa tidak mampu menjawab sesuai dengan indikator yang diberikan. Secara rinci sebagai berikut:

1. $70 \%$ siswa tidak mampu menyatakan ulang konsep

2. $65 \%$ siswa tidak mampu mengklasifikasikan objek-objek berdasarkan konsep matematika

3. $90 \%$ siswa tidak mampu menerapkan konsep secara algoritma

4. $75 \%$ siswa tidak mampu memberikan contoh atau kontra contoh dari konsep yang telah dipelajari

5. dan $60 \%$ siswa tidak mampu menyajikan konsep dalam berbagai representasi matematis.

Berdasarkan penelitian Murizal dkk (2012) diperoleh informasi bahwa kurangnya pemahaman konsep matematis siswa dikarenakan kebanyakan siswa tidak mampu mendefinisikan kembali bahan pelajaran matematika dengan bahasa mereka sendiri.Hal ini bertentangan dengan salah satu indikator pemahaman konsep matematis yang digunakan pada penelitian ini yaitu menyatakan ulang konsep yang telah dipelajari (Lestari\&Yudhanegara, 2017).Demikian juga dari hasil penelitian Mawaddah \& Mariyanti (2016) menunjukkan bahwa rendahnya kemampuan pemahaman konsep siswa tentang materi geometri sehingga matematika dianggap pelajaran yang sulit dan menyebabkan nilai rata-rata hasil belajarnya menjadi rendah yang terlihat berada di bawah KKM yaitu sebesar 65 pada UTS. Dari hasil penelitian disimpulkan bahwa pemahaman konsep matematis siswa perlu diperbaiki agar siswa dapat mengaplikasikan konsep secara tepat dan efisien dalam proses pembelajaran matematika.

HasilProgramme for International Student Assesment(PISA) tahun 2012 melaporkan bahwa berdasarkan analisis terakhir dalam literasi sains, 15 tahun di Indonesia mencetak 382 poin dibandingkan dengan rata-rata 501 poin di negara-negara lain. Hal ini menunjukkan penguasaan konsep anak-anak Indonesia masih kurang dibandingkan dengan negara lain dikarenakan masih terdapat kesulitan dalam memahami konsep-konsep (Puspitasari, 2017).

Berdasarkan latar belakang masalah tersebut, peneliti menemukan permasalahan dalam matematika yang harus diperbaiki. Permasalahan yang dimaksud adalah bagaimana siswa lebih dapat memahami konsep matematika dan melatih siswa untuk aktif serta kreatif dalam mengerjakan soal-soal matematika serta dapat terjalinnya hubungan interpersonal antara siswa dengan siswa untuk saling bekerja sama agar siswa paham dengan konsep matematika.

Adapun salah satu model pembelajaran yang dapat digunakan ialah model pembelajaran Scaffolding. Model pembelajaran Scaffolding berasal dari teori belajar Vigotsky, dalam teori belajar Vigotsky mengemukakan tentang Zona Perkembangan Proksimal (Zone of proximal development atau 
ZPD). Dimana perkembangan seseorang dapat dibedakan ke dalam dua tingkat, yaitu tingkat perkembangan aktual dan tingkat perkembangan potensial. Tingkat perkembangan aktual tampak dari kemampuan seseorang untuk menyelesaikan tugas-tugas dan memecahkan berbagai masalah secara sendiri. Sedangkan tingkat perkembangan potensial tampak dari kemampuan seseorang untuk menyelesaikan tugas-tugas dan memecahkan masalah ketika dibimbing orang dewasa atau ketika berkolaborasi dengan teman sebaya yang lebih mampu atau kompeten (Risnawati \& Zubaidah, 2015). Lebih lanjut, Scaffolding merupakan model pembelajaran yang memberikan sejumlah besar bantuan kepada seorang anak selama tahap awal pembelajaran kemudian anak tersebut mengambil alih tanggung-jawab yang semakin besar untuk dapat melakukannya. Bantuan tersebut berupa petunjuk, peringatan, dorongan, menguraikan masalah ke dalam langkah pemecahan, memberikan contoh sehingga siswa tersebut tumbuh mandiri (Puspitasari, 2017). Terkait hal tersebut, Hasil penelitian Rahmawati (2016), Sari \& Surya (2017), Alkher dkk (2018), dan Yuliani \& Widana (2018) memberikan gambaran secara umum bahwa penggunaan Scaffoldingdapat meningkatkan hasil belajar matematika siswa. Penelitian yang mengkhususkan hasil belajar pada aspek pemahamandilakukan oleh Nicke dkk (2014) menunjukkan bahwa pemahaman konsep matematis siswa yang menggunakan model pembelajaran Scaffolding lebih baik dari pada pemahaman konsep matematis siswa yang menggunakan pembelajaran konvensional. Hal ini sependapat dengan peneliti menduga Scaffoldingmasih relevan untuk meningkatkan kemampuan pemahaman konsep matematis siswa diwaktu sekarang.

Faktor lain yang juga menentukan keberhasilan siswa dalam menerima pelajaran adalah Self Efficacy.Menurut Bandura Self Efficacy sebagai penilaian seseorang terhadap kemampuannya untuk mengorganisasikan dan melaksanakan sejumlah tingkah laku yang sesuai dengan unjuk kerja (performance) yang dirancangnya (Risnawati \& Zubaidah, 2015). Dengan kata lain, Self Efficacy adalah suatu pendapat atau keyakinan yang dimiliki oleh seseorang mengenai kemampuannya dalam menampilkan suatu bentuk perilaku dan hal ini berhubungan dengan situasi yang dihadapi oleh seseorang tersebut. Self Efficacy akan mempengaruhi siswa pada pencapaian akademik. Seringkali siswa tidak mampu menunjukkan prestasi akademisnya secara optimal sesuai dengan kemampuan yang dimilikinya. Salah satu penyebabnya adalah karena siswa sering merasa tidak yakin bahwa dirinya akan mampu menyelesaikan tugas-tugas yang dibebankan kepadanya. Oleh karena itu, Self Efficacy dalam pembelajaran matematika penting untuk diketahui guru dan siswa dalam proses pembelajaran (Risnawati \& Zubaidah, 2015).

Berdasarkan uraian tersebut, maka peneliti tertarik untuk melakukan penelitian dengan judul "Pengaruh Penerapan Model Pembelajaran Scaffolding Terhadap Kemampuan Pemahaman Konsep Matematis Berdasarkan Self Efficacy Siswa SMP”. Adapun rumusan masalah pada penelitian ini adalah:

1. Apakah terdapat perbedaan kemampuan pemahaman konsep matematis siswa yang belajar dengan model pembelajaran Scaffolding dengan siswa yang belajar menggunakan pembelajaran langsung?

2. Apakah terdapat perbedaan kemampuan pemahaman konsep matematis siswa yang belajar dengan model pembelajaran Scaffolding dengan siswa yang belajar menggunakan pembelajaran langsung, Jika ditinjau dari Self Efficacy siswa?

3. Apakah terdapat interaksi antara penerapan model pembelajaran dengan Self Efficacy terhadap kemampuan konsep matematis?

\section{METODE}

Metode penelitian ini adalah eksperimen semu (quasi eksperimen). Penelitian eksperimen semu (quasi eksperimen) dipilih karena peneliti ingin menerapkan suatu tindakan atau perlakuan. Tindakan dapat berupa model, strategi, metode, atau prosedur kerja baru untuk meningkatkan 
efisiensi dan efektivitas pekerjaan agar hasilnya menjadi lebih optimal. Desain yang digunakan peneliti adalah Nonequivalent Posttest-Only Control Group Design. Desain penelitian ini dipilih karena peneliti hanya ingin melihat kemampuan pemahaman konsep siswa setelah diberikan tindakan atau perlakuan selama proses penelitian. Populasi dalam penelitian ini adalah seluruh siswa kelas VIII SMP Negeri 40 Pekanbaru. Teknik pengambilan sampel penelitian ini menggunakan teknik Purposive Sampling. Pengambilan sampel memerhatikan pertimbangan bahwa kelas yang dipilih adalah kelas yang pelajaran matematikanya diajar oleh guru yang sama. Hal ini diperkuat dengan hasil tes kemampuan pemahaman konsep matematis awal untuk membuktikan dua kelas yang peneliti ambil sebagai sampel penelitian adalah kelas-kelas dengan rata-rata nilai kemampuan pemahaman konsep matematis yang relatif sama dan memiliki karakteristik yang tidak jauh berbeda. Sampel dalam penelitian ini sebanyak dua kelas, kelas VIII A sebagai kelas eksperimen dan kelas VIII C sebagai kelas kontrol. Waktu penelitian dilaksanakan pada semester genap tahun ajaran 2018/2019 di SMP Negeri 40 Pekanbaru yang beralamat di Jalan Garuda Sakti.

Teknik pengumpulan data pada penelitian ini adalah angket Self Efficacy, tes pemahaman konsep matematis dan lembar observasi. Angket digunakan untuk mengelompokkan siswa ke dalam kategori Self Efficacy tinggi, sedang, dan rendah. Tes kemampuan pemahaman konsep matematis digunakan untuk mengukur kemampuan pemahman konsep matematis siswa pada materi Kubus dan Balok yang berbentuk uraian dan sudah diujicobakan terlebih dahulu dan memperoleh hasil valid dan reliabel, dan lembar observasi digunakan untuk melihat ketercapaian peneliti dan siswa dalam menerapkan model pembelajaran Scaffolding pada setiap pertemuan. Angket Self Efficacy dan soal tes pemahaman konsep matematis diberikan kepada kedua kelas sampel dengan instrumen yang sama. Hasil tes tersebut digunakan untuk membandingkan kemampuan pemahaman konsep matematis siswa berdasarkan Self Efficacy akibat dari perlakuan yang berbeda yang diberikan di kelas eksperimen dan kelas kontrol. Teknik analisis data pada penelitian ini menggunakan uji $t$ dan uji anova dua arah.

Adapun hipotesis pada penelitian ini adalah sebagai berikut:

1. $\mathrm{H}_{0}$ : tidak terdapat perbedaan kemampuan pemahaman konsep matematis siswa yang belajar dengan model pembelajaran Scaffolding dengan siswa yang belajar menggunakan pembelajaran langsung

Ha : terdapat perbedaan kemampuan pemahaman konsep matematis siswa yang belajar dengan model pembelajaran Scaffolding dengan siswa yang belajar menggunakan pembelajaran langsung

2. $\mathrm{H}_{0}$ : tidak terdapat perbedaan kemampuan pemahaman konsep matematis siswa yang belajar dengan model pembelajaran Scaffolding dengan siswa yang belajar menggunakan pembelajaran langsung, Jika ditinjau dari Self Efficacy siswa

$\mathrm{H}_{\mathrm{a}}$ : tidak terdapat perbedaan kemampuan pemahaman konsep matematis siswa yang belajar dengan model pembelajaran Scaffolding dengan siswa yang belajar menggunakan pembelajaran langsung, Jika ditinjau dari Self Efficacy siswa

3. $\mathrm{H}_{0}$ : tidak terdapat interaksi antara penerapan model pembelajaran dengan Self Efficacy terhadap kemampuan konsep matematis

$\mathrm{H}_{\mathrm{a}}$ : terdapat interaksi antara penerapan model pembelajaran dengan Self Efficacy terhadap kemampuan konsep matematis

\section{HASIL DAN PEMBAHASAN}

Berdasarkan hasilakumulasi lembar observasi sebanyak enam pertemuan diperoleh hasil bahwa keterlaksanaan guru dalam menerapkan model pembelajaran Scaffolding sebesar 92,63\% dan keterlaksanaan siswadalam menerapkan model pembelajaran Scaffolding siswa sebesar 89,93\%. Terdapat peningkatan setiap pertemuan baik itu hasil observasi kegiatan guru maupun hasil observasi kegiatan siswa.Artinya, keterlaksanaan proses pembelajaran sangat baik. 
Hasil uji angket digunakan untuk mengelompokkan siswa ke dalam kelompok Self Efficacytinggi, sedang, dan rendah. Siswa yang memperoleh skor sama atau lebih dari 88,81 berarti siswa tersebut termasuk ke dalam siswa yang memiliki Self Efficacytinggi. Sedangkan siswa yang skornya antara 74,55 sampai 88,81 termasuk siswa yang memiliki Self Efficacysedang. Apabila siswa memperoleh skor sama atau kurang dari 74,55 maka siswa tersebut termasuk ke dalam siswa yang memilki Self Efficacy rendah.

Setelah hasil posttest kemampuan pemahaman konsep matematis dilakukan uji normalitas dan homogenitas pada sampel, maka selanjutnya dilakukan uji hipotesis 1 yaitu uji-t dikelas eksperimen dan kelas kontrol. Hasil uji-t selengkapnya dapat dilihat pada tabel berikut:

Tabel 1. Hasil Uji-t

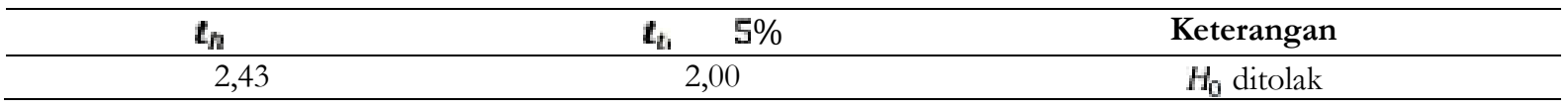

Berdasarkan hasil perhitungan $t_{\text {nit }}$ dibandingkan dengan $t_{t}$, nilai $t_{\text {nit }}=2,43$. Sedangkan nilai $t_{t_{1}} \quad$ dengan derajat kebebasan $(\mathrm{dk})=N_{x}+N_{y}-2=38+40-2=76$ pada tarafsignifikan 5\% adalah 2,00, hal ini berarti bahwa $t_{\text {nit }}>\tau_{t_{1}}$, maka $H_{0}$ ditolak. Artinya, terdapat pengaruh kemampuan pemahaman konsep matematis siswa yang belajar menggunakan model pembelajaran Scaffolding dengan siswa yang belajar menggunakan pembelajaran konvensional. Hasil penelitian ini masih relevan dengan hasil penelitian sebelumnya oleh Sudarman \& Linuhung (2017), Rismawati \& Handayani (2018), Rachmawati (2019), Lestari \& Andriani (2019)yang menunjukkan bahwa terdapat perbedaan kemampuan pemahaman konsep matematis antara kelas yang menggunakan model pembelajaran Scaffolding dibanding kelas konvensional, dimana kelas yang menggunakan model pembelajaran Scaffolding memiliki pemahaman konsep matematis yang lebih baik dari kelas konvensional. Hasil penelitian ini didukung Sidik (2016) dari temuan penelitiannya mengemukakan bahwa menggunakan scaffolding dalam membantu siswa yang mengalami kesulitan memahami permasalahan maka guru perlu memperhatikan pemahaman siswa terhadap penguasaan konsep matematika dengan memberikan analogi cerita nyata yang dekat dengan lingkungan siswa terkait materi yang dipelajari. Artinya melalui scaffoldingpemahaman matematika siswa akan lebih lama mengendap dalam pikiran.

Uji hipotesis 2 dan 3 maka digunakan uji ANOVA dua arah. Uji ini dilakukan untuk melihat secara langsung perbedaan yang terjadi dalam 3 variabel sekaligus. Berikut ini adalah hasil uji ANOVA dua arah yang disajikan dalam bentuk tabel beserta kesimpulan yang diperoleh dari tabel berikut:

Tabel 2. Hasil Uji Anova Dua Arah

\begin{tabular}{cccccc}
\hline Sumber varians & JK & Dk & RK & F & $\mathbf{F}_{\text {tabel }}$ \\
& 1125,43 & 2 & 562,72 & $F_{A}=1,83$ & 3,97 \\
\hline Antar A (Baris) & 2098,1 & 1 & 2098,1 & $F_{\text {U }}=6,85$ & 3,12 \\
\hline Antar B (Kolom) & 159,51 & 2 & 79,76 & $F_{A}=0,26$ & 3,12 \\
\hline Interaksi AB & 2063,5 & 72 & 723,10 & & - \\
\hline Dalam & & & & - \\
\hline
\end{tabular}

Antar baris (antar tingkat self efficacy), harga $F_{\text {nit }}<F_{t_{1}}$, yaitu $1,83<3,97$ maka $\mathrm{H}_{0}$ diterima. Hal ini berarti jika ditinjau dari Self Efficacy tidak terdapat perbedaan kemampuan pemahaman konsep matematis siswa yang mengikuti pembelajaran Scaffolding dengan siswa yang mengikuti pembelajaran konvensional. Untuk interaksi harga $F_{\text {nit }}<F_{t_{1}} \quad e$, yaitu $0,26<3,12$ maka $\mathrm{H}_{0}$ diterima. Hal ini berarti tidak terdapat pengaruh interaksi antara model pembelajaran Scaffolding dengan Self Efficacy terhadap kemampuan pemahaman konsep matematis siswa. Tidak 
terdapat interaksi pada penelitian ini diduga karena Menurut Hendriana, Rohaeti \&Sumarmo (2017) aspek pemahaman konsep masih tergolong pada tingkat berpikir rendah, sedangkan menurut Mukhid (2009) mengatakan bahwa ketika seorang mengeluarkan usaha yang besar dalam melaksanakan tugas yang dirasakan sulit maka Self Efficacy siswa terbangun kokoh.Dari kedua pernyataan tersebut, artinya kemampuan pemahaman konsep yang tergolong kemampuan matematis tingkat rendah tidak membutuhkan Self Efficacysiswa. Dengan kata lain, model pembelajaran dan Self Efficacytidak saling mempengaruhi dalam upaya peningkatan kemampuan pemahaman konsep matematis siswa.

Tes kemampuan pemahaman konsep yang dilakukan pada akhir pertemuan materi Kubus dan Balok ini menghasilkan nilai siswa yang akan ditinjau dari masing-masing indikatornya dan tingkat Self Efficacy(tinggi, sedang, atau rendah). Jawaban antara siswa kelas eksperimen dan kelas kontrol pada kelompok tinggi sudah benar dalam menyatakan ulang sebuah konsep, akan tetapi kedua kelas belum tepat dalam pemberian jawaban yang diinginkan. Namun jawaban pada kelas eksperimen lebih baik dari pada kelas kontrol terlihat pada jawaban yang diberikan oleh kelas eksperimen. Jawaban antara siswa kelas eksperimen dan kelas kontrol pada kelompok sedang kedua kelas sudah baik dalam menyatakan ulang sebuah konsep, akan tetapi jawaban belum sempurna karena hasil akhir terdapat kekurangan. Pada kelas eksperimen siswa mampu menjawab dengan baik dan tepat, tetapi pada siswa kontrol siswa juga mampu menjawab dengan baik, namum terdapat sedikit kekurangan dalam menjawab persoalan yang diberikan. Jawaban antara siswa kelas eksperimen dan kelas control kelompok rendah untuk hasil jawaban kelas eksperimen mampu menjawab dengan benar dalam menyatakan ulang sebuah konsep, sedangkan pada kelas kontrol terdapat kesalahan dalam proses menjawab.

Jawaban antara siswa kelas eksperimen dan kelas kontrol kelompok tinggi pada kedua kelas sudah benar dalam memberikan contoh atau kontra contoh dari konsep yang telah dipelajari. Pada kelompok sedang hasil jawaban kedua kelas sudah benar dalam pemberian contoh atau bukan contoh, akan tetapi jawaban belum sempurna karena hasil akhir terdapat kekurangan. Pada kelompok rendah sil jawaban kelas eksperimen mampu menjawab dengan benar dalam pemberian contoh dan bukan contoh, sedangkan pada kelas kontrol terdapat kesalahan dalam proses menjawab.

Jawaban antara siswa kelas eksperimen dan kelas kontrol pada kelompok tinggi untuk hasil jawaban kedua kelas sudah benar dalam mengklasifikasikan objek-objek berdasarkan konsep matematika, akan tetapi kedua kelas belum tepat dalam pemberian jawaban yang diinginkan. Namun jawaban pada kelas eksperimen lebih baik dari pada kelas kontrol terlihat pada jawaban yang diberikan oleh kelas eksperimen. Pada kelompok sedang, Untuk hasil jawaban kedua kelas sudah baik dalam mengklasifikasikan objek-objek berdasarkan konsep matematika, akan tetapi jawaban belum sempurna karena hasil akhir terdapat kekurangan. Pada kelas eksperimen siswa mampu menjawab dengan baik dan tepat, tetapi pada siswa kontrol siswa juga mampu menjawab dengan baik, namum terdapat sedikit kekurangan dalam menjawab persoalan yang diberikan. Pada kelompok rendah, Untuk hasil jawaban kelas eksperimen mampu menjawab dengan benar dalam mengklasifikasikan objek-objek berdasarkan konsep matematika, sedangkan pada kelas kontrol terdapat kesalahan dalam hasil jawaban.

Jawaban antara siswa kelas eksperimen dan kelas control pada kelompok tinggi dalam menyajikan konsep dalam berbagai representasi sudah benar namun belum sempurna. Jawaban pada kelas eksperimen sudah benar dan dalam penggunaan rumus juga sudah tepat sehingga jawaban pada kelas eksperimen benar sampai akhir. Jawaban pada kelas kontrol untuk penggunaan rumus sudah benar, akan tetapi pada tahap akhir terdapat kekurangan sehingga kelas kontrol tidak menemukan hasil akhirnya. Pada kelompok sedang, Untuk jawaban kedua kelas dalam menyajikan konsep dalam berbagai representasi sudah benar namun belum sempurna. Jawaban pada kelas eksperimen sudah benar dan dalam penggunaan rumus juga sudah tepat sehingga jawaban pada kelas eksperimen benar sampai akhir. Jawaban pada kelas kontrol untuk 
penggunaan rumus sudah benar, akan tetapi pada tahap akhir terdapat kekurangan sehingga kelas kontrol tidak menemukan hasil akhirnya. Pada kelompok rendah, ntuk jawaban kedua kelas dalam menyajikan konsep dalam berbagai representasi sudah benar namun belum sempurna. Jawaban pada kelas eksperimen sudah benar dan dalam penggunaan rumus juga sudah tepat sehingga jawaban pada kelas eksperimen benar sampai akhir. Jawaban pada kelas kontrol untuk penggunaan rumus sudah benar, akan tetapi pada tahap akhir terdapat kekurangan sehingga kelas kontrol tidak menemukan hasil akhirnya.

Jawaban antara siswa kelas eksperimen dan kelas kontrol pada kelompok tinggi untuk jawaban kedua kelas dalam menerapkan konsep secara algoritma sudah benar namun belum sempurna. Jawaban pada kelas eksperimen sudah benar dan dalam penggunaan rumus juga sudah tepat sehingga jawaban pada kelas eksperimen benar sampai akhir. Jawaban pada kelas kontrol untuk penggunaan rumus sudah benar, akan tetapi pada tahap akhir terdapat kekurangan sehingga kelas kontrol tidak menemukan hasil akhirnya. Pada kelompok sedang, jawaban kedua kelas dalam menerapkan konsep secara algoritma sudah benar namun belum sempurna. Jawaban pada kelas eksperimen sudah benar dan dalam penggunaan rumus juga sudah tepat sehingga jawaban pada kelas eksperimen benar sampai akhir. Jawaban pada kelas kontrol untuk penggunaan rumus sudah benar, akan tetapi pada tahap akhir terdapat kekurangan sehingga kelas kontrol tidak menemukan hasil akhirnya. Pada kelompok rendah, jawaban kedua kelas dalam menerapkan konsep secara algoritma sudah benar namun belum sempurna. Jawaban pada kelas eksperimen sudah benar dan dalam penggunaan rumus juga sudah tepat sehingga jawaban pada kelas eksperimen benar sampai akhir. Jawaban pada kelas kontrol untuk penggunaan rumus sudah benar, akan tetapi pada tahap akhir terdapat kekurangan sehingga kelas kontrol tidak menemukan hasil akhirnya.

Dari kelima indikator ini rata-rata dan nilai yang rendah adalah indikator menerapkan konsep secara algoritma. Dalam hal ini siswa masih kesulitan dalam menerapkan konsep secara logis yang berkenaan dengan pemecahan masalah. Siswa masih sulit dalam menentukan apa yang harus dilakukan terlebih dahulu dalam menerapkan konsep. Dalam menerapkan konsep secara algoritma tersebut siswa terlebih dahulu harus memperhatikan apa yang diketahui dalam soal, apa yang akan ditanya dan langkah apa yang harus dilakukan. Namun kebanyakan dari siswa hanya melihat apa yang ditanya di dalam soal sehingga mereka hanya menggunakan rumus tanpa mengetahui apa yang harus dijabarkan sebelumnya.

Indikator yang memperoleh jumlah skor terbesar dari seluruh indikator yang ada adalah memberikan contoh atau kontra contoh dari konsep yang telah dipelajari. Untuk indikator ini hampir semua siswa sudah mampu dengan baik menuliskan jawabannya secara baik dan benar.

\section{KESIMPULAN}

Hasil penelitian ini menunjukkan bahwa:

1. Terdapat perbedaan kemampuan pemahaman konsep matematis siswa yang belajar dengan model pembelajaran Scaffolding dengan siswa yang belajar menggunakan pembelajaran konvensional.

2. Tidak terdapat perbedaan kemampuan pemahaman konsep matematis siswa dengan model pembelajaran Scaffolding dengan siswa yang menggunakan pembelajaran konvensional ditinjau berdasrkan Self Efficacy siswa.

3. Tidak terdapat interaksi antara model pembelajaran dengan Self Efficacy terhadap kemampuan pemahaman konsep matematis siswa. 


\section{REFERENSI}

Alkher, M. S., Edristi, S., \& Lovia, L. (2018). "Pengaruh Penerapan Pembelajaran Scaffolding terhadap Hasil Belajar Matematika Siswa SMP Kelas VII”.Jurnal Ilmiah Mahasiswa STKIP PGRI Sumateri Barat.

Depdiknas. (2006). Kurikulum Tingkat Satuan Pendidikan (KTSP). Jakarta: Depdiknas.

Hendriana, H., Rohaeti, E. E.,\& Sumarmo, U. (2017). Hard Skills dan Soft Skills. Bandung: PT Refika Aditama.

Lestari, K. E.,\&Yudhanegara, R. (2017). Penelitian Pendidikan Matematika. Bandung: PT Refika Aditama.

Lestari, S. I. \& Andriani, L. (2019). "Pengaruh Penerapan Strategi Pembelajaran Scaffolding Terhadap Kemampuan Pemahaman Konsep Matematis Siswa Madrasah Tsanawiyah AlHidayah Singingi Hilir Ditinjau dari Motivasi Belajar Siswa". Suska Journal of Mathematics Education. Vol. 5. No. 1.

Mawaddah, S. \& Mariyanti, R. (2016). "Kemampuan Pemahaman Konsep Matematis Siswa SMP Dalam Pembelajaran Menggunakan Model Penemuan Terbimbing (Discovery Learning)", Jurnal Pendidikan Matematika Vol. 4 No. 1.

Mukhid, A. (2009)."Self Efficacy: Perspektif Teori Kognitif Sosial dan Implikasinya terhadap Pendidikan”, Jurnal Tadris Vol. 4, No.1.

Murizal, A., dkk. (2012) "Pemahaman Konsep Matematis Dan Model Pembelajaran Quantum Teaching"Jurnal Pendidikan Matematika.Vol. 1, No. 1.

Nicke, S., Irwan, \& Meira. (2014)"Pengaruh Penerapan Pendekatan Scaffolding Terhadap Kemampuan Pemahaman Konsep Matematika Siswa Kelas VIII SMP Pertiwi 2 Padang".Jurnal Pendidikan Matematika. Vol. 3, No. 3.

Puspitasari, M. D. M., (2017). "Strategi Pemecahan Masalah Siswa Pada Pretest Konsep Materi Kalor", Jurnal Berkala Ilmiah Pendidikan Fisika, Vol. 5, No. 1.

Rachmawati, I. (2019). "Penggunaan Teknik Scaffolding pada Pembelajaran Matematika Untuk Meningkatkan Kemampuan Pemahaman Matematik Pada Siswa SMP”. Jurnal Equation. Vol. 2. No. 2.

Rahmawati, F. (2016). "Pengaruh Penerapan Model Pembelajaran Scaffolding terhadap Hasil Belajar Matematika pada Siswa Kelas VIII Semester Ganjil SMP Negeri 30 Bandar Lampung". Lentera Jurnal Ilmiah Kependidikan STKIP-PGRI Bandar Lampung. Vol. 1.

Rismawati \& Handayani, H. (2018). "Pengaruh Strategi Scaffolding terhadap Kemampuan Pemahaman Matematis Siswa Sekolah Dasar" Jurnal Silogisme. Vol. 3 No. 3.

Risnawati \& Amir, Z. (2015). Psikologi Pembelajaran Matematika. Yogyakarta: Aswaja Pressindo.

Sari, N. \& Surya, E. (2017). "Efektivitas Penggunaan Teknik Scaffolding dalam Mengingkatkan Hasil Belajar Matematika pada Siswa SMP Swasta Al- Washliyah Medan”. Edumatica Jurnal Pendidikan Matematika. Vol. 7. No. 1.

Sidik, G. S. (2016). "Analisis Proses Berpikir dalam Pemahaman Matematis Siswa Sekolah Dasar dengan Pemberian Scaffolding". Jurnal Pendidikan Sekolah Dasar. Vol. 2. No. 2.

Sudarman, S. W. \& Linuhung, N. (2017). "Pengaruh Pembelajaran Scafolding terhadap Pemahaman Konsep Integral Mahasiswa". Aksioma: Jurnal Pendidikan Matematika FKIP Univ. Mubammadiyah Metro. Vol. 6. N0.1.

Yuliani, N. L. G. \& Widana, I. W. (2018). Pengaruh Model Pembelajaran Scaffolding Berbantuan Multimedia Interaktif terhadap Hasil Belajar Matematika dengan Mengontrol Gaya Berpikir Siswa SMP Negeri 2 Mengwi. Jurnal Emasains. Vol. 7. No. 1. 